\title{
GRG Profiles: Lawrence S. Friedman
}

\author{
Lawrence S. Friedman
}

Published online: 3 March 2015

(C) Springer Science+Business Media New York 2015

I was born in Newark, New Jersey, in 1953. My parents were highly respected high school teachers in the Newark school system, and my father became a high school vice principal. My earliest memories are of accompanying my father to school activities, from concerts to sporting events, and I enjoyed the academic environment, music, and sports. He taught History, English, and Latin, and I came to love language and learning and became a student of American history. My mother taught secretarial subjects and was a guidance counselor. She was pragmatic, nurturing, and absolutely devoted to family. I had a younger sister, Lois, who later became a speech therapist. When I was five, we moved to the suburb of Springfield, and I experienced what can only be described as an idyllic childhood, spanning the staid 1950s and the increasingly turbulent 1960s. I excelled in school, loved basketball, and played tenor saxophone, clarinet, and flute in a variety of bands; I had a passion for Big band jazz.

I was fortunate to attend Princeton University, where I decided to major in biology and prepare for medical school. Although my goal was to be an educator, I realized that I wanted to keep up with scientific advances and that

L. S. Friedman

Harvard Medical School, Boston, MA, USA

L. S. Friedman

Tufts University School of Medicine, Boston, MA, USA

L. S. Friedman ( $₫)$

The Anton R. Fried, MD, Chair, Department of Medicine, Newton-Wellesley Hospital, 2014 Washington Street, Newton, MA 02462, USA

e-mail: 1friedman@partners.org

L. S. Friedman

Massachusetts General Hospital, Boston, MA, USA medicine would allow me to pursue my natural inclination to help people and teach at a high level. When I was a sophomore, my father suggested that I apply to an accelerated program at the Johns Hopkins University School of Medicine that would allow me to shorten my formal education by a year. Perhaps he sensed that time was running out for him, because during my first year at Hopkins, he became ill and subsequently passed away. I had some comfort in knowing that he had the opportunity to see me launch my career in medicine.

\section{Hopkins}

Hopkins opened the world of medicine to me. I had remarkable classmates, including G. William Dec, Michael Laposata, Keith D. Lillemoe, and David W. Rattner, who would later become my colleagues at the Massachusetts General Hospital (MGH), and dazzling professors, many of whom were accomplished scientists and all of whom were outstanding clinicians and teachers. The academic expectation at Hopkins was to become a "triple threat." I was most inspired by the grand clinicians who seemed to pull diagnoses out of a hat and provided virtuoso instruction at the bedside. Chief among them was Philip A. Tumulty, the heir apparent to Sir William Osler. Others included Willis C. Maddrey, Stephen C. Achuff (a cardiologist), Mary Betty Stevens (a rheumatologist), and Victor A. McKusick, the famed chief of medicine who had once been a leader in cardiology and had since become a pioneer in medical genetics. McKusick's prodigious scholarly output and command of English resonated with my desire to write. His distinctive Maine accent and idiosyncratic mannerisms were the objects of interest and imitation among the Hopkins community, and after a while, I became known as 
the best McKusick impersonator. I was asked to perform at Hopkins functions and was even filmed for the archives of the Johns Hopkins Hospital. McKusick was always a great sport about my performances.

My final year as a student at Hopkins was interrupted sadly by the death of my mother, and I had to postpone my required rotation in psychiatry until the end of the academic year. Had I not, I would never have met my future wife, Mary Jo Cappuccilli, a remarkable nurse, who had just transferred to psychiatry. My mother had looked out for me. Mary Jo and I, now married for 34 years and counting, have a son, Matthew, age 30, and a grandson, Christopher, age 7; she has been my rock and best teacher.

\section{MGH}

Influenced by Maddrey as well as other great gastroenterologists at Hopkins, including Thomas R. Hendrix and Theodore E. Bayless, and two chief residents, Richard S. Johannes and H. Franklin Herlong, I decided that after my residency at Hopkins I would pursue fellowship training in gastroenterology. I was fortunate to be accepted by Kurt J. Isselbacher at MGH, where I observed two distinctions from Hopkins. First, I was exposed much more directly to cutting-edge basic research by Isselbacher and others in the Gastrointestinal (GI) Unit. Isselbacher's work in galactosemia, bilirubin metabolism, intestinal absorption, alcoholic liver disease, and later GI cancer fueled my appreciation for scientific inquiry and discovery. Although I continued to pursue my passion as an educator, the close exposure to the scientific work conducted in the GI Unit helped to round out my training. Second, although teaching excellence was also valued at $\mathrm{MGH}$, the focus was on content, not process, which had been emphasized at Hopkins. I, therefore, was able to find a niche in which I could draw on the prodigious knowledge of experts at MGH to complement my interest in demonstrating clinical skills and reasoning to students and residents and therefore develop my role as a clinician-educator.

I had wonderful teachers and role models at MGH, including great clinicians such as Robert H. Schapiro and Stephen E. Goldfinger, outstanding clinical investigators, such as Jules L. Dienstag, excellent private practitioners, such as Bernard R. Aserkoff, and other successful basic scientists such as Jack R. Wands. I was also introduced to legendary GI Unit alumni, such as Norton J. Greenberger and J. Thomas LaMont. The other fellows, including Barbara J. Nath, Jerome B. Zeldis, Ira M. Jacobson, and Peter B. Kelsey, were talented, none moreso than Daniel K. Podolsky, who later succeeded Isselbacher as Chief of the GI Unit. Isselbacher, recognizing my interest in education and scholarship, provided ample opportunity for me to develop my skills. He even asked me to help him edit chapters for Harrison's Principles of Internal Medicine [1] and gave me my own chapter (on indigestion) in the next edition [2]. Isselbacher himself was a superb editor and demonstrated to me the exceptional care with which he handled his editorial responsibilities. I can vividly recall our discussions about a single sentence until we came up with just the right wording and emphasis. He also allowed me to pursue clinical, rather than basic, research, which emanated from problems I encountered in practice. For example, a study from Italy had just reported that treatment with enemas containing 5-aminosalicylic acid (mesalamine) was effective in ulcerative proctitis [3], and I was able to obtain 5-aminosalicylic acid, create my own enema formulation, and conduct a study that led to the publication of one of the first randomized controlled studies comparing 5-aminosalicylic acid enemas with standard glucocorticoid enemas [4].

With the goal of becoming a clinician-educator, I strived to see as many challenging cases as possible, report some of them [5], and become familiar with the literature across the breadth of gastroenterology and hepatology. I also sought opportunities to write articles and chapters with my senior instructors, including an uncredited contribution to a paper on acute pancreatitis with the great surgeon Andrew L. Warshaw [6-9].

\section{Jefferson}

Although I was asked to return to Hopkins as a chief medical resident, I decided instead to accept an offer to join Willis Maddrey at Jefferson Medical College, where he had just become Magee Professor of Medicine and Chairman of the Department. I worked with a group of excellent clinical gastroenterologists, including Susan J. Gordon and Steven R. Peikin, and with Maddrey's efforts, we later added more "firepower" with Santiago J. Munoz, Paul Martin, and the great esophagologist Donald O. Castell, among others. Maddrey gave me every opportunity to develop my interests in teaching and scholarship, and I became the Associate Director of the housestaff training program and later Vice Chairman of the Department of Medicine. Learning administration from Maddrey was like a second fellowship; he was a master. We attracted outstanding residents and superb fellows and innovated our training, and I collaborated with fellows and colleagues, including Maddrey, on a large number of scholarly publications, including a review on the assessment of surgical risk in patients with liver disease [10], a topic that I have continued to chronicle throughout my career [11].

With Maddrey's encouragement, I became active in some of our national gastroenterology and hepatology 
societies. I was turned down for the Training Committee by the American Gastroenterological Association (AGA) but was accepted for such a role by the American Society for Gastrointestinal Endoscopy (ASGE) after I shared a taxi ride with Barbara B. Frank, a fellow Philadelphian, who was about to become President-Elect of the ASGE. The ASGE Committee on Training did not meet during my first year on the committee because the chair was ill. I was surprised, therefore, when John H. Bond, Frank's successor as President-Elect, asked me to chair the committee the following year. I protested to Bond that I had no idea what the committee did, and he replied, "Nor does the Governing Board. Anything you do will be helpful." The assignment occurred at a time of great ferment in gastroenterology when the four principal societies were developing a federation with closer collaboration in areas such as public policy and training. I, therefore, found myself as one of the ASGE's representatives to an eightmember joint training committee of the four societies. Jacques Van Dam was the other ASGE representative, and the other six members were Eugene R. Schiff and Michael F. Sorrell representing the American Association for the Study of Liver Disease, Martin H. Flock and Walter L. Peterson representing the American College of Gastroenterology, and John L. Gollan and Bruce F. Scharschmidt representing the AGA. As a relatively junior member of this August group, I agreed to serve as secretary and produced detailed minutes of all our deliberations. The minutes, which summarized our planning of a core curriculum in gastroenterology, were distributed to the governing boards of the four societies, and I received positive feedback on their clarity, detail, and cogency. As a result, I was the unanimous choice to become the Chair of the GI Core Curriculum Project, an effort that involved over 100 gastroenterologists, culminated in a consensus conference at the Heart House in Bethesda, Maryland, where the final curriculum, over 100 pages in length, was assembled, and led to publication of the first-ever GI core curriculum [12]. The curriculum, which has been revised periodically, serves as the foundation for training in gastroenterology in the USA. It led to the requirement for three, rather than two, years of training in gastroenterology and the development of special requirements for training in transplant hepatology and advanced interventional endoscopy [13$16]$.

\section{MGH Again}

After Maddrey and Castell left Jefferson, I decided to accept an offer from my old friend Dan Podolsky, Chief of the GI Unit at MGH, to "return home" as a senior clinician-educator. In addition to having a major hand in the training of fellows and supervising their outpatient experience, I ultimately became a Firm Chief, one of the three senior housestaff teaching positions in the Department of Medicine. I again grew a busy consultative practice and continued to pursue my scholarship, often in collaboration with the outstanding fellows I had the privilege of working with. At one point, I had four chapters on four different subjects in four major textbooks of gastroenterology and hepatology [17-20]. The GI Unit under Podolsky was as stimulating as it had been under Isselbacher, and, in addition to my older colleagues, I worked with a new generation of superstars, including Timothy C. Wang, Anil K. Rustgi, Raymond T. Chung, Daniel C. Chung, Bruce E. Sands, James M. Richter, William R. Brugge, Peter B. Kelsey, Norman S. Nishioka, Lee M. Kaplan, Andrea E. Reid, Ramnik J. Xavier, and others. For me, this was academic heaven (once again).

I used to joke that when you come from MGH, people assume you know what you're talking about. Although I had always been academically productive, I suspect that some opportunities came my way in part because of the MGH imprimatur. I became a councilor and then treasurer of the ASGE, and I was invited to join the American Board of Internal Medicine, Subspecialty of Gastroenterology, where, for the final 4 years of my ten-year term, I served as chair. On both the ASGE Board and the ABIM, I had the opportunity to collaborate with the best and brightest of gastroenterology. My perspective was always that of a practicing gastroenterologist. On the ABIM, I was particularly sensitive to the time and regulatory constraints of contemporary practice, and I encouraged the Board to emphasize testing that was practical and clinically relevant rather than esoteric. Questions were to be based on a synthesis of data and clinical judgment rather than recall.

I was particularly honored to be invited by Marvin $\mathrm{H}$. Sleisenger and Mark Feldman to succeed Bruce Scharschmidt as co-editor of the seventh edition of Sleisenger and Fordtran's Gastrointestinal and Liver Disease: Pathophysiology/Diagnosis/Management [21]. Editing a book of this size and reputation was the ultimate academic fulfillment for me. Not only did I collaborate with outstanding editors, but I also reviewed chapters by the world's experts in each area of gastroenterology and considered each author to be my personal teacher. When Marvin Sleisenger stepped down after the seventh edition, we were fortunate to recruit Lawrence J. Brandt to work with Feldman and me as co-editor, and the three of us have now produced three editions of the book together [22]. Feldman and Brandt are superior editors with an encyclopedic knowledge of gastroenterology; Feldman has a knack for creating tables and figures of unsurpassed clarity and accuracy, and Brandt is the grammarian's grammarian. Working on the book with them has been exhilarating. 
A pet project of mine was The Handbook of Liver Disease, which I co-edited with Emmet B. Keeffe, another remarkable editor (also former editor of this journal) who sadly passed away after we completed our third edition [23]. This book was designed to be concise and practical ("user friendly") and has also allowed me to learn from experts in their fields. Emmet too was a gifted editor and valued friend.

\section{Newton-Wellesley Hospital}

In 2002, I represented MGH on a team negotiating with Newton-Wellesley Hospital (NWH) in neighboring Newton to merge our housestaff training programs. NWH had just joined Partners HealthCare, and MGH was planning to provide its housestaff with a much-needed community hospital experience. One of the tasks of the Negotiating Committee was to develop a job description for a new Chair of Medicine, and when that description was completed, I realized that it fit me to a "T": an excellent clinician with a passion for teaching and scholarship who could inspire higher levels of clinical performance and academic productivity. I felt that I had trained all my life for this position, which would allow me to develop an entire department in my image (without leaving Boston). NWH was already a strong institution with an outstanding private practice medical staff, and the infusion of $\mathrm{MGH}$ housestaff would make it an exceptional academic community hospital. I was impressed with the leadership of NWH. The president was Michael S. Jellinek, who had been the founding Chief of Child Psychiatry at MGH and had a clear vision for promoting clinical excellence. The chief medical officer, Leslie G. Selbovitz, had once been a senior resident in medicine and a dermatology resident at MGH and was a medical polymath with world-class expertise in healthcare quality and patient safety. I could not have asked for a better setting in which to be a chair of medicine.

The promise has indeed been fulfilled, and my experience at NWH has capped off a wonderful career. I am particularly proud that we have developed a first-class Hospitalist Service, built excellent subspecialty programs including a full-service Cancer Center and a first-rate Cardiovascular Center, and grown our primary care practices into emerging Patient-Centered Medical Homes. As Chair, I oversee the department's quality improvement and patient safety initiatives and housestaff and faculty recruitment. I work with a wonderful group of colleagues in gastroenterology, headed by Richard L. Curtis, a marvelous gastroenterologist, and greatly enjoy my professional interactions with members of the division, including Dennis E. Lee, Laurence S. Bailen, Elissa E. Kaplan, Benjamin E.
Levitzky, Vera K. Denmark, Carla H. Ginsburg, and Alexander Kopp, and with the entire Department of Medicine. I have been able to continue my academic and scholarly pursuits, although I miss working with GI fellows. Because of NWH's overlapping affiliations, I have the unique distinction of being the only Professor of Medicine at both Harvard Medical School and Tufts University School of Medicine.

For 6 years ending in 2014, I served as Chair of Digestive Disease Week Council and oversaw a strategic planning process that led to a more compact, relevant, and enjoyable meeting. I recently signed on for a second tourof-duty with the ABIM on the new Gastroenterology Board that focuses on policy and became a member of the Antiviral Drugs Advisory Committee of the Food and Drug Administration, where I have the opportunity to review all the exciting new agents that are becoming available for the treatment of hepatitis C. My consultative practice in gastroenterology, now with an emphasis on liver disease, has continued to flourish.

So, this is the biography of a clinician-educator, a role that I have cherished. My mission has been to help relieve suffering caused by gastrointestinal disease (and to guide others to do so), promote the development of young physicians as outstanding clinicians and educators, champion a career as a clinician-educator as an academic pursuit commensurate with that of investigation, and remain a lifelong student of gastroenterology. I hope my story inspires others to follow this career path [24].

\section{References}

1. Petersdorf RG, Adams RD, Braunwald E, Isselbacher KJ, Martin $\mathrm{JB}$, Wilson D, eds. Harrison's Principles of Internal Medicine. 10th ed. New York: McGraw-Hill; 1983.

2. Friedman LS, Isselbacher KJ. Indigestion. In: Braunwald E, Isselbacher KJ, Petersdorf RG, Wilson JD, Martin JB, Fauci AS, eds. Harrison's Principles of Internal Medicine. 11th ed. New York: McGraw-Hill; 1986:171-173.

3. Campieri M, Lanfranchi GA, Bazzocchi G, et al. Treatment of ulcerative colitis with high-dose 5-aminosalicylic acid enemas. Lancet. 1981;2:270-271.

4. Friedman LS, Richter JM, Kirkham SE, DeMonaco HJ, May RJ. 5-Aminosalicylic acid enemas in refractory distal ulcerative colitis: a randomized, controlled trial. Am J Gastroenterol. 1986;81:412-418.

5. Friedman LS, Kirkham SE, Thistlethwaite JR, Platika D, Kolodny EH, Schuffler MD. Jejunal diverticulosis with perforation as a complication of Fabry's disease. Gastroenterology. 1984;86:558-563.

6. Zeldis JB, Friedman LS, Isselbacher KJ. Ranitidine: a new H2receptor antagonist. N Engl J Med. 1983;309:1368-1373.

7. Friedman LS, Wands JR. Cirrhosis. In: Conn HF, ed. Current Therapy 1983. Philadelphia: WB Saunders; 1983:356-361.

8. Friedman LS, Dienstag JL. The disease and its pathogenesis. In: Gerety RJ, ed. Hepatitis A: The Disease and the Virus. New York: Academic Press; 1984:55-79. 
9. Haas GS, Warshaw AL, Daggett WM, Aretz HT. Acute pancreatitis after cardiopulmonary bypass. Am J Surg. 1985;149:508-515.

10. Friedman LS, Maddrey WC. Surgery in the patient with liver disease. Med Clin N Am. 1987;71:453-476.

11. Friedman LS. Preoperative evaluation of the patient with liver disease. In: Schiff ER, Sorrell MF, Maddrey WC, eds. Schiff's Diseases of the Liver. 11th ed. Philadelphia: Lippincott Williams and Wilkins; 2012:316-325.

12. Friedman LS, ed. Gastroenterology Leadership Council. Training the gastroenterologist of the future: the gastroenterology core curriculum. Gastroenterology. 1996; 110:1266-1300.

13. Friedman LS, Brandt LJ, Elta GH, et al. Report of the multisociety task force on GI training. Am J Gastroenterol. 2009;104: 2659-2663.

14. Friedman LS, Brandt LJ, Elta GH, et al. Report of the multisociety task force on GI training. Gastroenterology. 2009;137: 1839-1843.

15. Friedman LS, Brandt LJ, Elta GH, et al. Report of the multisociety task force on GI training. Gastrointest Endosc. 2009;70: 823-827.

16. Friedman LS, Brandt LJ, Elta GH, et al. Report of the multisociety task force on GI training. Hepatology. 2009;50:1325-1329.

17. Quirk DM, Friedman LS. Approach to gastrointestinal problems in the elderly. In: Yamada T, ed, Alpers DH, Laine L, Owyang C, Powell DW, assoc. eds. Textbook of Gastroenterology. 3rd ed. Philadelphia: Lippincott Williams and Wilkins; 1999:1015-1033.
18. Chung RT, Friedman LS. Liver abscess and bacterial, parasitic, fungal, and granulomatous liver disease. In: Feldman M, Friedman LS, Sleisenger MH, eds. Sleisenger \& Fordtran's Gastrointestinal and Liver Disease: Pathophysiology/Diagnosis/ Management. 7th ed. Philadelphia: Saunders; 2002:1343-1363.

19. Friedman LS, Martin P, Munoz SJ. Laboratory evaluation of the patient with liver disease. In: Zakim D, Boyer TD, eds. Hepatology: A Textbook of Liver Disease. 4th ed. Philadelphia: Saunders; 2003:661-708.

20. Rosenberg PM, Friedman LS. The liver in circulatory failure. In: Schiff ER, Sorrell MF, Maddrey WC, eds. Schiff's Diseases of the Liver. 9th ed. Philadelphia: Lippincott Williams and Wilkins; 2003:1327-1340.

21. Feldman M, Friedman LS, Sleisenger MH, eds. Sleisenger \& Fordtran's Gastrointestinal and Liver Disease: Pathophysiology/ Diagnosis/Management. 7th ed. Philadelphia: Saunders; 2002.

22. Feldman M, Friedman LS, Brandt LJ, eds. Sleisenger and Fordtran's Gastrointestinal and Liver Disease: Pathophysiology/ Diagnosis/Management. 10th ed. Philadelphia: Saunders Elsevier; 2016.

23. Friedman LS, Keeffe EB, eds. Handbook of Liver Disease. 3rd ed. Philadelphia: Saunders Elsevier; 2012.

24. Friedman LS. Becoming a clinician-educator: lessons learned. Gastroenterology. 2014;146:599-601. 